\title{
Peningkatan Partisipasi Relawan dan Pelaku Pariwisata dalam Pengelolaan Risiko Bencana di Kompleks Candi Borobudur
}

\author{
Khaerunnisa $^{1}$, Mutiara Cininta ${ }^{2}$, Yonathan Dri Handarkho ${ }^{3}$ \\ Universitas Atma Jaya Yogyakarta ${ }^{1,2,3}$, \\ J1. Babarsari No. 44, Janti, Caturtunggal, Kec. Depok, Kabupaten Sleman, Daerah Istimewa Yogyakarta \\ Email: khaerunnisa@uajy.ac.id
}

Received: December 27, 2021 ; Revised: -; Accepted for Publication December 28, 2021; Published: January 4, 2022

\begin{abstract}
Disaster Risk Management Plan in cultural heritage areas such as the Borobudur Temple Complex, should be the joint responsibility of all stakeholders. In fact, disaster management at the Borobudur Temple Complex, especially the preservation of the site against disasters, is only the responsibility of the Borobudur Conservation Center. Therefore, in September-November 2021 through the research activities funded by UNESCO, UAJY and BKB have formulated a draft Disaster Risk Management Plan in the form of the borobudur-drr.id digital platform. However, due to the limited implementation time, this platform has not been fully socialized by all stakeholders. Based on the stakeholder meeting, it is known that there are differences in understanding among stakeholders in understanding the comprehensive approach contained in the Disaster Risk Management Plan Action Plan for the Borobudur Temple Complex. The diversity of educational backgrounds, experiences and exposure of stakeholders to disasters and their management requires a forum for equalizing perceptions that supports the synergy of stakeholders in supporting, supervising and implementing the action plans that have been prepared. Conservationists, volunteers and tourism actors are three of the fifty-three stakeholders that have been mapped in the Borobudur Temple Compounds Disaster Risk Management Plan, which has a vital role in realizing the action plan in the Borobudur Temple Area.
\end{abstract}

Keywords-participation, management, disaster, world heritage site.

Abstrak-Disaster Risk Management Plan pada kawasan warisan budaya seperti Kompleks Candi Borobudur, sudah seharusnya menjadi tanggung jawab bersama seluruh pemangku kepentingan (stakeholders). Pada kenyataannya, manajemen bencana pada Kompleks Candi Borobudur terutama kelestarian situs terhadap bencana hanya menjadi tanggung jawab Balai Konservasi Borobudur. Maka pada bulan September-November 2021, dengan kegiatan penelitian yang didanai oleh UNESCO, UAJY dan BKB telah merumuskan draft Disaster Risk Management Plan dalam bentuk platform digital borobudur-drr.id. Namun demikian, dikarenakan keterbatasan waktu implementasi, platform ini belum sepenuhnya sosialisasikan oleh seluruh stakeholders. Berdasarkan stakeholders meeting, diketahui adanya perbedaan pemahaman di antara stakeholders dalam memahami pendekatan komprehensif yang tertuang dalam Rencana Aksi Disaster Risk Management Plan Kompleks Candi Borobudur. Keberagaman latar belakang pendidikan, pengalaman dan paparan stakeholders terhadap bencana dan manajemennya memerlukan sebuah forum penyamaan persepsi yang mendukung sinergitas stakeholders dalam mendukung, mengawasi dan mengimplementasikan rencana aksi yang telah disusun. Pelestari, Relawan dan Pelaku pariwisata adalah tiga dari lima puluh tiga stakeholder yang telah dipetakan dalam Borobudur Temple Compounds Disaster Risk Management Plan, yang memiliki peran vital dalam perwujudan rencana aksi di Kawasan Candi Borobudur.
Kata Kunci-partisipasi, pengelolaan, bencana, situs warisan dunia.

\section{PENDAHULUAN}

Properti Warisan Dunia dan situs warisan budaya memiliki kecenderungan terdampak oleh bencana alam maupun bencana yang diakibatkan oleh manusia. Hal ini dapat mengancam integritasnya dan dapat membahayakan nilainya. Hilangnya atau rusaknya properti yang luar biasa ini memiliki dampak negatif yang parah pada komunitas lokal dan nasional, baik karena makna penting budayanya, maupun karena nilai sosial ekonominya.

Dalam konteks properti Warisan Dunia, bencana dapat menyebabkan hilangnya Outstanding Universal Value (OUV) serta kondisi keaslian dan integritas yang dimiliki; dan akibatnya, signifikansi sosial budaya dan ekonomi yang terkait bagi komunitas lokal dan masyarakat yang disengaja mungkin akan hilang. [1] Penguatan tata kelola risiko bencana untuk mengelola risiko bencana adalah salah satu pilar Warisan dalam kebijakan PRB dapat dicapai dengan melalui visi, rencana, kompetensi, bimbingan, dan koordinasi yang jelas di dalam dan lintas sektor tata kelola risiko, serta partisipasi pemangku kepentingan terkait [2].

Desentralisasi kepemimpinan dan wewenang manajemen risiko bencana ke tingkat regional, kotamadya atau lokal memungkinkan koordinasi sukarelawan yang lebih efektif dalam fase kesiapsiagaan dan tanggap darurat. Hal ini dapat mendorong partisipasi pemangku kepentingan lokal dan memicu orang-orang untuk terlibat menjadi sukarelawan berdasarkan motivasi kepentingan diri mereka sendiri dan pertimbangan kesejahteraan bersama. Desentralisasi yang disertai dengan partisipasi multi-stakeholder dalam proses perencanaan juga menciptakan suasana yang lebih inklusif dan mengarah pada partisipasi masyarakat yang lebih besar. Kemitraan dengan masyarakat yang berisiko terdampak bencana dapat meningkatkan kapasitas lokal dan mekanisme penanggulangan untuk merespon. Meningkatnya kesadaran akan risiko dalam masyarakat menginspirasi lebih banyak orang untuk terlibat untuk mencegah hilangnya mata pencaharian mereka sendiri [3].

Disaster Risk Management Plan (DRMP) pada kawasan warisan budaya seperti Kompleks Candi Borobudur, sudah seharusnya menjadi tanggung jawab bersama seluruh pemangku kepentingan (stakeholders). Pada kenyataannya, manajemen bencana pada Kompleks Candi Borobudur 
terutama kelestarian situs terhadap bencana hanya menjadi tanggung jawab Balai Konservasi Borobudur (BKB). Pada tahun 2021, dengan pendanaan dari UNESCO, UAJY dan BKB telah merumuskan draft Disaster Risk Management Plan (DRMP) dalam bentuk platform digital borobudurdrr.id. Namun demikian, dikarenakan keterbatasan waktu implementasi, platform ini belum sepenuhnya sosialisasikan kepada seluruh stakeholders.

Berdasarkan stakeholders meeting penelitian sebelumnya yang didanai UNESCO dan Japanese Funds-inTrusts yang dilaksanakan pada tanggal 2 November 2021, diketahui adanya perbedaan pemahaman di antara stakeholders dalam memahami pendekatan komprehensif yang tertuang dalam Rencana Aksi Disaster Risk Management Plan Kompleks Candi Borobudur. Keberagaman latar belakang pendidikan, pengalaman dan paparan stakeholders terhadap bencana dan manajemennya memerlukan sebuah forum penyamaan persepsi yang mendukung sinergitas stakeholders dalam mendukung, mengawasi dan mengimplementasikan rencana aksi yang telah disusun. Pelestari, Relawan dan Pelaku pariwisata adalah tiga dari lima puluh tiga stakeholder yang telah dipetakan dalam Borobudur Temple Compounds Disaster Risk Management Plan, yang memiliki peran vital dalam perwujudan rencana aksi di Kawasan Candi Borobudur.

Pengabdian ini bertujuan untuk memetakan dan meningkatkan partisipasi pemangku kepentingan di tingkat lokal dalam penyelenggaraan Disaster Risk Management Plan di Warisan Dunia Kompleks Candi Borobudur untuk Relawan dan Pelaku Pariwisata melalui kegiatan sosialisasi dan focus group discussion. Secara jangka panjang, pengabdian ini bertujuan untuk mewujudkan kesiapsiagaan Kawasan Candi Borobudur dalam menghadapi multi-hazard disasters.

Target sasaran program ditentukan berdasarkan temuan permasalahan di lapangan, yaitu (i) meningkatnya pemahaman antar stakeholders terhadap fase-fase disaster risk management (DRM) dan (ii) terpetakannya potensi elaborasi pemangku kepentingan dalam mendukung pelaksanaan rencana aksi DRM. Adapun target sasaran tersebut ialah: relawan (Komunitas Vihara Mendut, dan Young Guardian Club Borobudur), dan pelaku pariwisata (Komunitas Pedagang dan Persatuan Pramuwisata Indonesia). Gambar 1 menunjukkan diagram pengelompokan stakeholder sasaran program.

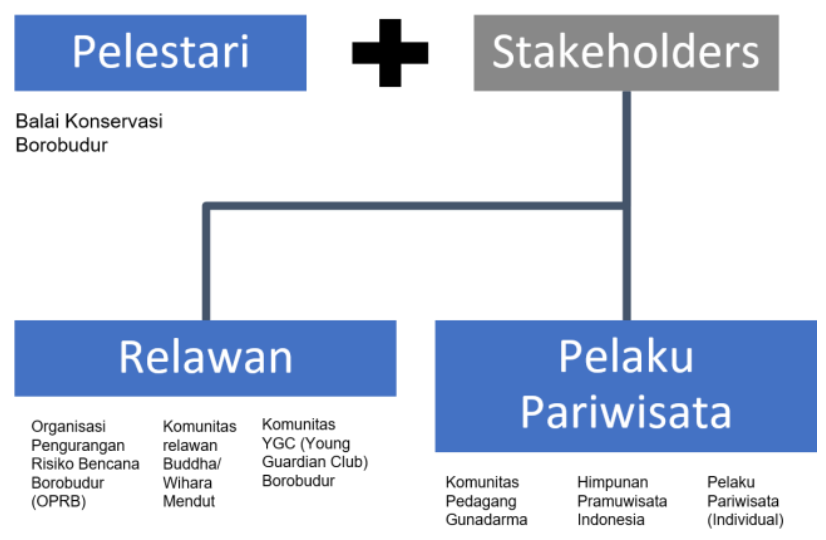

Gambar 1 Diagram Mitra dan Target Sasaran Kegiatan

\section{Metode Pengabdian}

Metode penyampaian yang diusulkan untuk penyampaian program pengembangan kapasitas mencakup konsultasi manajemen (pendekatan "berfokus pada proses") dan pelatihan bantuan teknis (pendekatan "berfokus pada keterampilan") [4]. Aktivitas Knowledge Sharing ditujukan untuk peningkatan kapasitas seluruh stakeholders yang mendukung pemahaman dasar terkait disaster risk management plan. Focus Group Discussion digunakan sebagai media untuk dapat memetakan peran pemangku kepentingan dalam manajemen bencana di Kawasan Candi Borobudur. Focus Group Discussion juga digunakan sebagai media untuk mengukur peningkatan tingkat pemahaman responden terhadap fase-fase pengelolaan bencana. Focus group discussion telah diakui dan banyak digunakan akhirakhir ini, terutama dikarenakan metode ini memiliki keunggulan dari segi kemudahan, keuntungan ekonomis, high face validity, dan juga hasil yang cepat [5]. Beberapa penulis juga mengandalkan FGD karena metode ini menekankan pada interaksi sosial namun terarah yang menguntungkan dalam proses mengumpulkan data [6] [7].

Penyampaian akan dilakukan secara luring kepada pemangku kepentingan (stakeholder) yang menjadi target sasaran program. Implementasi akan dibagi menjadi 2 sesi yang berdasarkan perbedaan intensi masing-masing kategori stakeholder: relawan dan pelaku wisata. Hal ini ditujukan supaya diskusi dapat lebih intensif dan terfokus berdasarkan garis besar minat kelompok. Tabel 1 menunjukkan distribusi peserta workshop Capacity Building 20-21 Desember 2021. 
Tabel 1. Persebaran Jumlah Peserta Berdasarkan Asal Komunitas

\begin{tabular}{|l|l|c|}
\hline $\begin{array}{l}\text { Pemangku } \\
\text { Kepentingan }\end{array}$ & Asal Organisasi/Komunitas & Jumlah \\
\hline Relawan & Young Guardian Club (YGC) & 9 \\
\cline { 2 - 3 } & Relawan Buddha/Wihara Mendut & 6 \\
\cline { 2 - 3 } & $\begin{array}{l}\text { Organisasi Pengurangan Risiko } \\
\text { Bencana Borobudur (OPRB) }\end{array}$ & 9 \\
\hline $\begin{array}{l}\text { Pelaku } \\
\text { Pariwisata }\end{array}$ & Komunitas Pedagang Gunadarma & 7 \\
\cline { 2 - 3 } & $\begin{array}{l}\text { Himpunan Pramuwisata } \\
\text { Indonesia }\end{array}$ & 10 \\
\cline { 2 - 3 } & Pelaku Pariwisata (Individual) & 8 \\
\hline Total Responden & $\mathbf{4 9}$ \\
\hline
\end{tabular}

Salah satu luaran lain dari program ini adalah infografis yang bertujuan untuk menjadi pedoman stakeholder dalam memahami perannya dalam fase-fase manajemen resiko bencana. Untuk meningkatkan perbendaharaan kontribusi pemangku kebijakan, pengabdi memproduksi infografis dengan ilustrasi gambar yang menarik dan mudah dipahami. Pendekatan visual infografis mampu menggantikan paparan informasi dan data yang rumit [8]. Visual yang kuat juga lebih mudah diingat, penelitian membuktikan walaupun hanya melihat dalam waktu yang singkat manusia dapat mengingat hingga ribuan gambar [9]. Oleh karena itu penggunaan media infografis sebagai media penyampaian diharapkan dapat menjangkau lebih banyak pemangku kepentingan dengan latar belakang kemampuan pemahaman yang beragam dan juga dapat dijadikan referensi ketika keadaan mendesak.

Dalam pendistribusiannya, material tersebut akan dapat dicetak secara fisik untuk diberikan kepada stakeholders maupun didistribusikan secara elektronik untuk mengedukasi masyarakat umum yang mungkin terkait. Infografis yang didistribusikan secara fisik diharapkan dapat dipasang

Metode evaluasi keberhasilan pengabdian ini merujuk pada definisi pengabdian kepada masyarakat sebagai kegiatan yang mencakup upaya-upaya peningkatan kualitas sumber daya manusia antara lain dalam hal perluasan wawasan, pengetahuan maupun peningkatan keterampilan yang dilakukan oleh civitas akademika sebagai perwujudan dharma bakti serta wujud kepedulian untuk berperan aktif meningkatkan kesejahteraan dan memberdayakan masyarakat luas terlebih bagi masyarakat ekonomi lemah [10]. Definisi ini diturunkan ke dalam poin-poin evaluasi yang meliputi kontribusi pengabdian ini pada peningkatan kemandirian masyarakat, pemenuhan kebutuhan masyarakat, peningkatan kemampuan berpikir dan keterampilan, peningkatan daya nalar masyarakat dan penyelesaian permasalahan terkait manajemen risiko bencana di Kompleks Candi Borobudur.

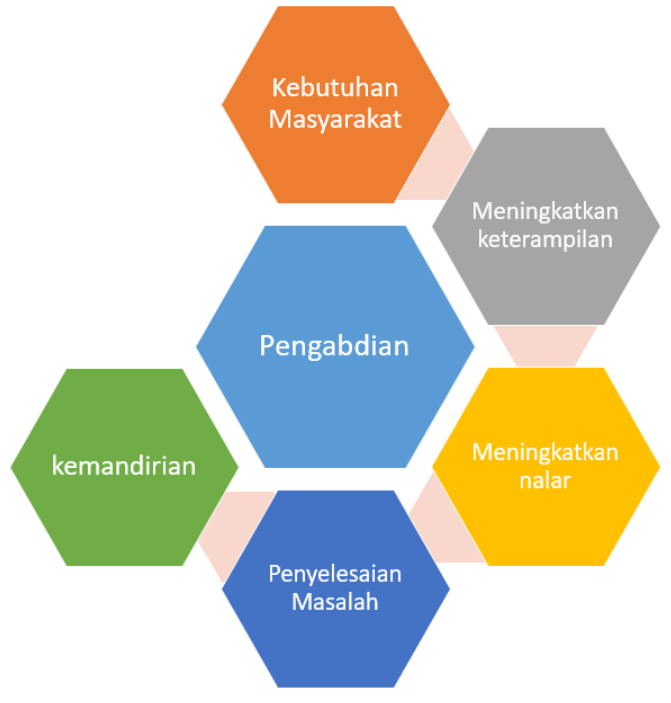

Gambar 2 Lima elemen evaluasi pengabdian

\section{HASIL DAN PEMBAHAAN}

Pembahasan hasil pengabdian ini dikategorikan kedalam dua bagian yaitu (1) peningkatan kapasitas dan pemetaan potensi keikutsertaan pemangku kebijakan dalam pengelolaan risiko bencana di kompleks candi borobudur dan (2) evaluasi pemangku kebijakan terhadap program pengabdian.

\section{A. Peningkatan Kapasitas dan Partisipasi Pengelolaan Bencana}

Panduan Disaster Risk Management Cycle for Cultural Heritage (UNESCO) menunjukkan bahwa fase bencana dibagi menjadi tiga kategori utama berdasarkan lini waktu (Gambar 2). Fase pada saat terjadinya bencana atau sering disebut fase tanggap darurat adalah fase dimana penyelamatan nyawa, dan aset cagar budaya dilakukan. Fase setelah terjadinya bencana atau fase recovery, bertujuan untuk mengembalikan kembali kondisi dengan pengaplikasian prinsip build back better, untuk mengurangi risiko hilangnya aset cagar budaya di masa mendatang. Fase sebelum terjadinya bencana biasanya disebut juga fase kesiapsiagaan bencana, secara lini masa merupakan fase terpanjang di keseluruhan siklus bencana. Fase ini biasanya diisi dengan kegiatan-kegiatan yang dapat meningkatkan

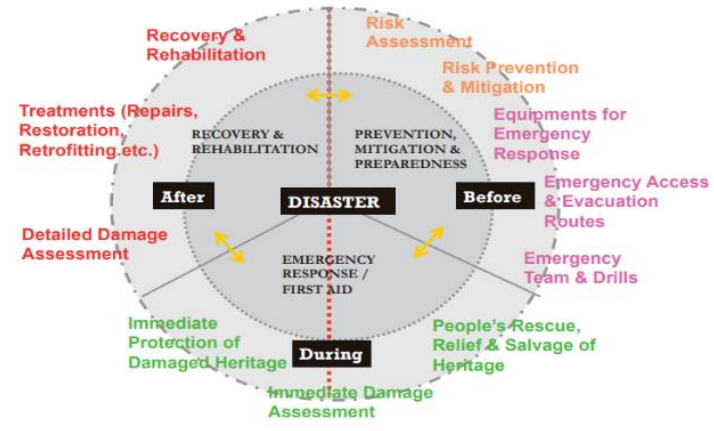

Gambar 3 Disaster Risk Management cycle for Cultural Heritage (UNESCO) Source: [11] 
ketangguhan bencana seperti peningkatan kepedulian dan kesadaran bencana, tindakan perkuatan aset cagar budaya sebagai usaha pengurangan risiko bencana.

Dalam Pengabdian ini, salah satu luaran yang dihasilkan adalah 6 (enam) infografis terkait kontribusi pemangku kepentingan dalam pengelolaan risiko bencana di Kompleks Candi Borobudur. Infografis yang dibuat disesuaikan dan dikategorikan dengan kebutuhan pemahaman responden terkait fase-fase pengelolaan bencana. Tabel 2 menunjukkan jenis infografis dan kaitannya dengan fase pengelolaan bencana. Infografis ini disusun sebagai media edukasi yang diharapkan dapat membantu responden untuk memahami fase-fase pengelolaan bencana dengan menggunakan contoh-contoh nyata yang diilustrasikan secara komunikatif. Infografis yang diberikan kepada pemangku kepentingan secara cetak ini diharapkan bisa digunakan sebagai media edukasi dalam komunitas secara berkelanjutan, meskipun program pengabdian kepada masyarakat ini telah berakhir.

\begin{tabular}{|l|l|l|}
\hline \multicolumn{2}{|l|}{$\begin{array}{l}\text { Tahapan Manajemen Resiko } \\
\text { Bencana }\end{array}$} & Tema Infografis \\
\hline Fase 1 & Tanggap Darurat & $\begin{array}{l}\text { Panduan Evakuasi: } \\
\text { - Erupsi Gunung Api } \\
\text { - Gempa Bumi }\end{array}$ \\
\hline Fase 2 & $\begin{array}{l}\text { Recovery dan } \\
\text { Rehabilitasi }\end{array}$ & $\begin{array}{l}\text { Panduan Memasang Terpal } \\
\text { Panduan Membersihkan } \\
\text { Candi }\end{array}$ \\
\hline Fase 3 & $\begin{array}{l}\text { Kesiapsiagaan dan } \\
\text { Pengurangan Risiko } \\
\text { Bencana }\end{array}$ & $\begin{array}{l}\text { Panduan yang perlu dijelaskan } \\
\text { ketika berkunjung } \\
\text { Panduan Patroli: Identifikasi } \\
\text { ATHG }\end{array}$ \\
\hline
\end{tabular}

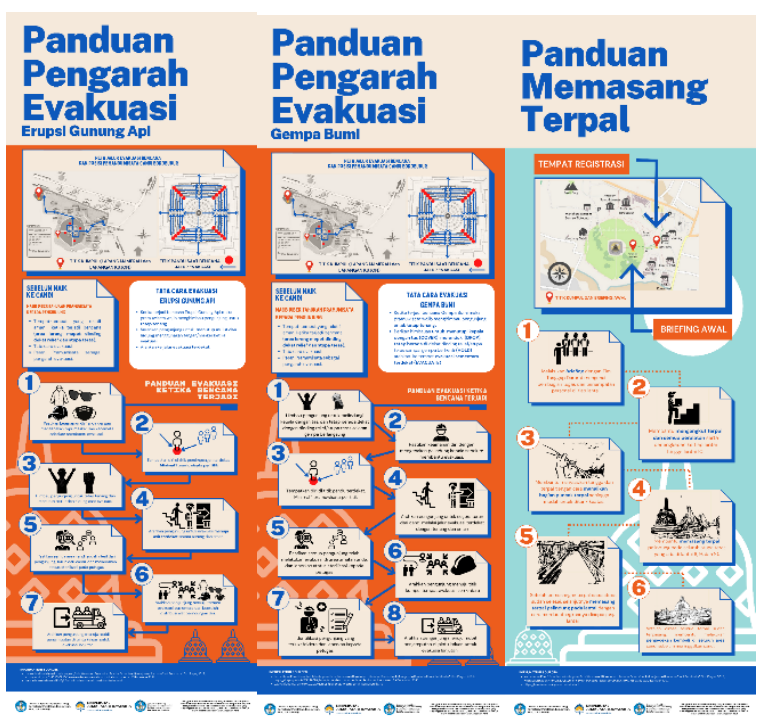

Gambar 4. Fase 1 Tanggap Darurat
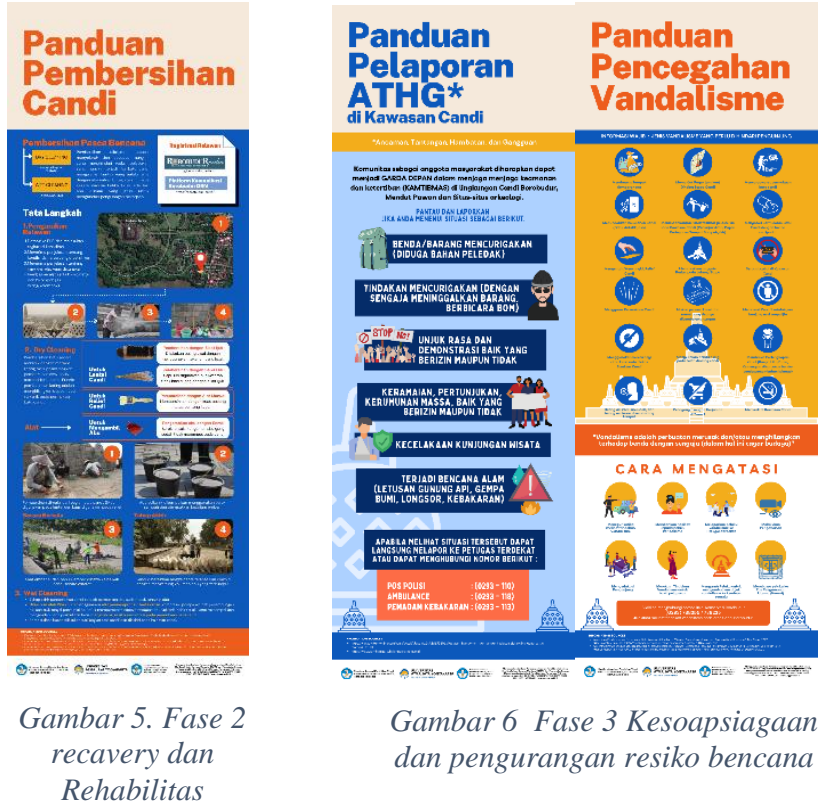

Gambar 6 Fase 3 Kesoapsiagaan dan pengurangan resiko bencana

Secara terperinci, pemetaan potensi keikutsertaan pemangku kebijakan tercantum pada Tabel 3. Warna biru pada Tabel 3, menunjukkan opsi kontribusi yang masih dikategorikan pada fase kebencanaan yang salah. Secara garis besar, pemangku kepentingan sudah bisa mengkategorikan dan mengasosiasikan peran sesuai dengan fase pengelolaan risiko bencana. Berdasarkan pemangku kepentingan, Komunitas Wihara Mendut, dan Young Guardian Club (YGC), dan pelaku pariwisata (individu) memiliki pemahaman yang sangat baik terhadap fase-fase bencana. Hal ini terlihat pada hasil focus group discussion yang menunjukkan tingginya pengkategorian opsi pada fase pengelolaan bencana yang benar, yakni antara 80-100\% (Tabel 3). Kerancuan penggolongan aksi masih terlihat cukup banyak dilakukan oleh OPRB, Komunitas Pedagang dan Himpunan Pramuwisata Indonesia yang menunjukkan penggolongan tindakan dalam fase pengelolaan bencana yang benar berkisar antara 50-66.7\%. Berdasarkan analisis tersebut di atas, maka perlu adanya perhatian khusus untuk meningkatkan pemahaman pemangku kepentingan terutama pedagang dan HPI untuk dapat memahami fase-fase pengelolaan bencana dan variasi pilihan opsi yang memungkinkan.

Berdasar pada fase pengelolaan bencana, kerancuan penggolongan kategori aksi dapat terlihat paling banyak terdapat pada fase tanggap darurat. Akan tetapi, jika melihat pada persebaran opsi yang ditawarkan oleh pemangku kepentingan, terlihat bahwa baik relawan maupun pelaku pariwisata bersedia terlibat di hampir setiap tahap pengelolaan bencana di Kompleks Candi Borobudur. Opsiopsi terkait koordinasi pembersihan candi dalam internal komunitas relawan dan pelaku pariwisata dimungkinkan dengan mengelaborasi media komunikasi whatsapp group yang selama ini telah digunakan. Meskipun demikian, kesepakatan pembagian peran perlu disepakati antara Pelestari dalam hal ini Balai Konservasi Borobudur dan para pemangku kepentingan, sehingga tercipta hubungan timbal 
balik yang saling menguntungkan antara kedua belah pihak dalam koridor pelestarian situs warisan dunia.

Tabel 3 Sebaran Opsi Pengelolaan Bencana berdasarkan pemangku kepentingan

\begin{tabular}{|c|c|c|c|c|c|c|c|}
\hline \multirow[t]{2}{*}{ Fase } & \multirow[t]{2}{*}{ Opsi } & \multicolumn{3}{|c|}{ Relawan } & \multicolumn{3}{|c|}{$\begin{array}{l}\text { Pelaku } \\
\text { Pariwisata }\end{array}$} \\
\hline & & $\begin{array}{l}\dddot{\dddot{x}} \\
\frac{\dddot{a}}{0}\end{array}$ & $\frac{\pi}{\frac{\pi}{0}}$ & ড & 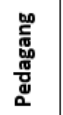 & 호 & z⿸\zh14 \\
\hline \multirow[t]{4}{*}{$\begin{array}{l}\text { Tanggap } \\
\text { Darurat }\end{array}$} & $\begin{array}{l}\text { Komunikasi dan } \\
\text { Informasi }\end{array}$ & $\bullet$ & $\bullet$ & $\bullet$ & & & $\bullet$ \\
\hline & \begin{tabular}{|l|} 
Donasi \\
\end{tabular} & & $\bullet$ & & & & \\
\hline & Koordinasi & $\bullet$ & $\bullet$ & $\bullet$ & $\bullet$ & & $\bullet$ \\
\hline & $\begin{array}{l}\text { Sarana dan prasarana } \\
\text { evakuasi }\end{array}$ & & $\bullet$ & & $\bullet$ & $\bullet$ & \\
\hline \multirow{5}{*}{$\begin{array}{l}\text { Recovery dan } \\
\text { Rehabilitasi }\end{array}$} & Pembersihan Candi & & & $\bullet$ & $\bullet \bullet$ & & \\
\hline & \begin{tabular}{|l|} 
Donasi \\
\end{tabular} & & & $\bullet$ & & & \\
\hline & Koordinasi relawan & & $\bullet$ & & $\bullet$ & & \\
\hline & \begin{tabular}{|l|} 
Pendataan \\
\end{tabular} & & & & & $\bullet \bullet$ & \\
\hline & Konseling & $\bullet$ & & & & & \\
\hline \multirow{7}{*}{$\begin{array}{l}\text { Kesiapsiagaan } \\
\text { Bencana }\end{array}$} & Campaign & & & $\bullet \bullet \bullet$ & $\bullet$ & & \\
\hline & $\begin{array}{l}\text { Workshop, Edukasi \& } \\
\text { sosial media }\end{array}$ & & $\bullet$ & $\bullet$ & $\bullet$ & $\bullet$ & $\bullet \bullet$ \\
\hline & \begin{tabular}{|l|}
$\begin{array}{l}\text { Pembentukan } \\
\text { komunitas }\end{array}$ \\
\end{tabular} & $\bullet$ & $\bullet$ & & & & \\
\hline & Simulasi & & & $\bullet$ & & $\bullet$ & $\bullet$ \\
\hline & \begin{tabular}{|l|} 
Pelaporan \\
\end{tabular} & $\bullet$ & $\bullet$ & $\bullet$ & & & \\
\hline & \begin{tabular}{|l|} 
Mitigasi \\
\end{tabular} & $\bullet$ & & & & & $\bullet$ \\
\hline & Regulasi & & & & & $\bullet$ & \\
\hline \multicolumn{2}{|c|}{ Jumlah Opsi dalam fase yang benar } & 4 & 8 & 7 & 3 & 3 & 4 \\
\hline \multicolumn{2}{|c|}{ Jumlah Opsi dalam fase yang salah } & 2 & 0 & 1 & 3 & 2 & 1 \\
\hline \multicolumn{2}{|c|}{ Prosentase opsi yang benar (\%) } & 66.7 & 100 & 87.5 & 50.0 & 60.0 & 80.0 \\
\hline
\end{tabular}

\section{B. Evaluasi pemangku kebijakan terhadap program pengabdian}

Kuesioner survei terhadap kepuasan mitra dilakukan untuk memberikan gambaran pelaksanaan program pengabdian dalam rangka mencapai tujuannya. Kuesioner survei dilakukan dengan membandingkan antara harapan dan kepuasan peserta terhadap program pengabdian. Berdasarkan hasil kuesioner (Gambar 7 dan Gambar 8), terlihat bahwa baik pelaku pariwisata maupun relawan memiliki harapan yang tinggi terhadap program pengabdian ini. Hal ini ditunjukkan dengan banyaknya responden yang memilih kategori harapan yang tinggi dan sangat tinggi di setiap elemen penilaiannya. Jika dibandingkan antara harapan dan kepuasan, dapat terlihat adanya kecenderungan peningkatan persentase responden yang memilih kategori tinggi dan sangat tinggi. Hal ini menunjukkan bahwa adanya pemenuhan harapan yang melebihi ekspektasi para responden. Peningkatan pemenuhan harapan yang signifikan terlihat pada pemenuhan kebutuhan masyarakat pada kelompok pelaku pariwisata dan meningkatnya keterampilan pada kelompok relawan.

\section{PELAKU PARIWISATA}

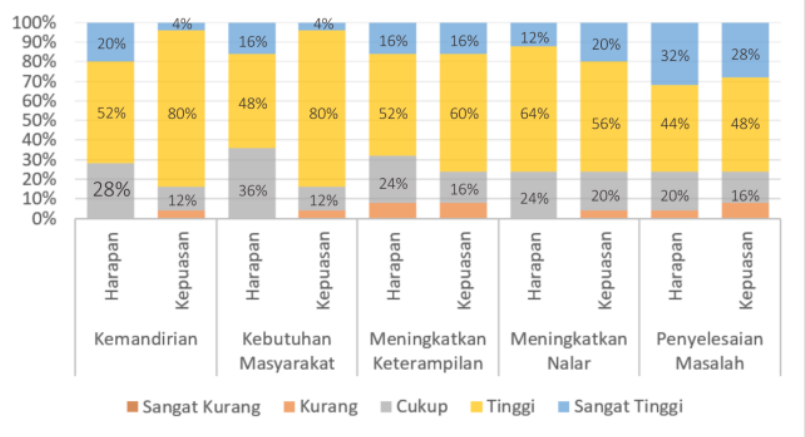

Gambar 7 Harapan dan Kepuasan pelaku pariwisata terhadap program pengabdian

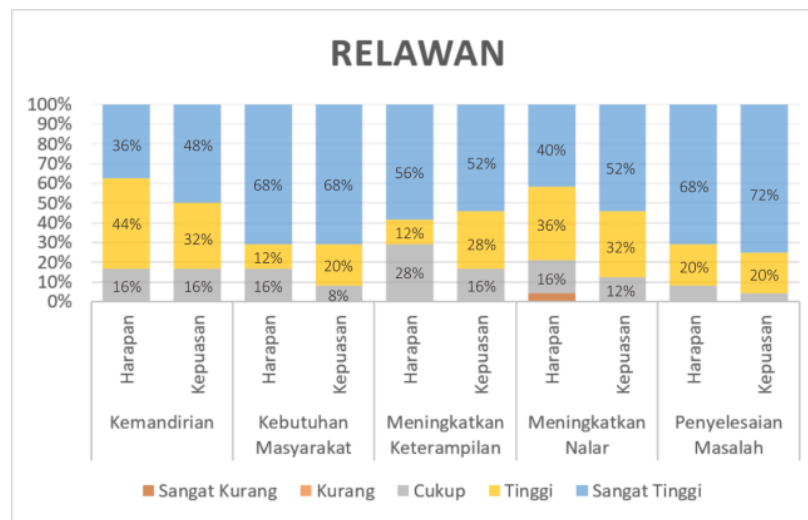

Gambar 8 Harapan dan kepuasan Relawan terhadap program pengabdian

\section{KESIMPULAN}

Dalam pengabdian ini diketahui bahwa para pemangku kepentingan di tingkat lokal, khususnya para relawan dan pelaku pariwisata bersedia terlibat di hampir setiap tahap pengelolaan bencana. Opsi-opsi pengelolaan risiko bencana juga telah dapat dirumuskan secara mandiri melalui media focus group discussion. Peserta pengabdian juga sebagian besar telah mampu untuk menggolongkan opsi-opsi kontribusi masing-masing komunitas ke dalam fase pengelolaan bencana. Meskipun demikian, peningkatan pemahaman dan variasi opsi perlu terus dieksplorasi lebih lanjut terutama untuk para pedagang dan pramuwisata yang lokasi berada di dalam area Kompleks Candi Borobudur. Berdasarkan evaluasi kepuasan mitra, terlihat bahwa harapan peserta pada saat mengikuti kegiatan ini sudah terpenuhi, terutama terkait peningkatan kemandirian dan kontribusi dan keterlibatan peserta dalam pengelolaan bencana di situs warisan dunia Kompleks Candi Borobudur. Diperlukan koordinasi yang memungkinkan adanya pembagian peran baik secara vertikal maupun horizontal untuk mengakomodasi keberlanjutan luaran pemetaan peran yang dihasilkan dari pengabdian ini. 


\section{UCAPAN TERIMAKASIH}

Ucapan terima kasih kami haturkan kepada Direktorat Jenderal Pendidikan Tinggi Kementerian Pendidikan, Kebudayaan, Riset, dan Teknologi yang telah mendukung terlaksananya pengabdian masyarakat ini melalui Bantuan Pendanaan Program Penelitian Kebijakan Merdeka Belajar Kampus Merdeka (MBKM) dan Pengabdian kepada Masyarakat Berbasis Hasil Penelitian dan Purwarupa PTS Tahun Anggaran 2021, serta Universitas Atma Jaya Yogyakarta yang sudah memfasilitasi program pengabdian ini. Selain itu, kami mengucapkan terima kasih juga untuk Balai Konservasi Borobudur (BKB) yang telah menjadi mitra pelestari yang membantu kelancaran pelaksanaan program pengabdian kepada masyarakat ini.

\section{DAFTAR PUSTAKA}

[1] M. Ravankhah, "Earthquake Disaster Risk Assessment for Cultural World Heritage Sites: The Case of 'Bam and its Cultural Landscape' in Iran," 2020.

[2] UNESCO, "Reducing Disasters Risks at World Heritage Properties," 2021, [Online]. Available: https://whc.unesco.org/en/disaster-riskreduction/.

[3] S.Zubirc and H. Amirrol, "Disaster risk reduction through community participation,” WIT Trans. Ecol. Environ., 2011, doi: 148. 195-206. 10.2495/RAV110191.

[4] T. E. Backer, "Strengthening Nonprofits," in Building Capacity in Nonprofit Organizations: Foundation Initiatives for Nonprofit Organizations, C. J. De Vita and C. Fleming, Eds. The Urban Institute, 2001.

[5] R. A. Krueger, "Focus Groups: A Practical Guide for Applied Research," Sage Publ. Inc., 1988, doi: 10.2307/3172912.

[6] R. . Merton, M. Fiske, and P. . Kendal, "The Focused Interview: A Manual of Problems and Procedures," Free Press, vol. 2nd, 1990.

[7] D. L. Morgan, "Focus Groups," Annu. Rev. Sociol., 1996, doi: http://dx.doi.org/10.1146/annurev.soc.22.1.129.

[8] M. B. Arigia, T. Damayanti, and A. Sani, "Infografis Sebagai Media Dalam Meningkatkan Pemahaman Dan Keterlibatan Publik Bank Indonesia," J. Komun., 2016, [Online]. Available: https://journal.untar.ac.id/index.php/komunikasi/article/view/63/145.

[9] W. F. Senjaya et al., "PERAN INFOGRAFIS SEBAGAI PENUNJANG DALAM PROSES PEMBELAJARAN SISWA,” $J$. Pengabdi. Kpd. Masy., 2019, doi: doi.org/10.24071/altruis.2019.020108.

[10] Direktorat Riset dan Pengabdian kepada Masyarakat Universitas Indonesia, Renstra Pengabdian Masyarakat. Depok, 2016.

[11] R. Jigyasu, "Reducing Disaster Risks to Urban Cultural Heritage: Global Challenges and Opportunities," J. Herit. Manag., vol. 1, pp. 59-67, 2016, doi: https://doi.org/10.1177/2455929616649476.

\section{PENULIS}

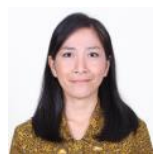

Khaerunnisa, prodi Arsitektur, Fakultas Teknik, Universitas Atma Jaya Yogyakarta.

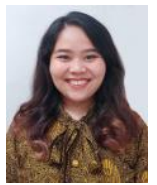

Mutiara Cininta, prodi Arsitektur, Fakultas Teknik, Universitas Atma Jaya Yogyakarta.

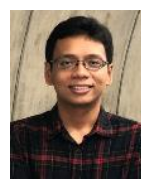

Yonathan Dri Handarkho, prodi Informatika, Fakultas Teknologi Industri, Universitas Atma Jaya Yogyakarta. 